\title{
Observations on a Queenless Colony of Plebeia Saiqui (Friese) (Hymenoptera, Apidae, Meliponinae)
}

\author{
VERA LUCIA IMPERATRIZ-FONSECA \\ MARIA AUGUSTA CABRAL DE OLIVEIRA \\ Departamento de Zoologia, Instituto de Biociências da Universidade \\ de São Paulo
}

\section{A B S T R A C T}

Observations on building, provisioning, oviposition and operculation in a queenless colony of Plebeia saqui (Friese) are described. The normal aspect and behaviour showed by the orphan bees could be explained due to the fact that the colony had a great number of workers.

By the third month, modifications in the processes and in the behaviour were observed and queen-like behaved workers were found.

Nectar dehydrating and work with cerumen are mentioned as being also male activities.

Other observations are also described as the reutilization of empty cells and problems of oophagy, as well as the shape and the size of the combs.

\section{R E S U M O}

O presente trabalho descreve observações feitas em uma colônia órfã de Plebeia saqui (Friese), com relação a construção, ao aprovisionamento, a oviposição e à operculação das células. Durante três meses as operárias apresentaram uma construção de células regular, que poderia ser resultante do grande número de abelhas existentes na colmeia, ou uma característica do gênero.

Por volta do $3 .^{\circ}$ mês os processos de aprovisionamento e oviposição modificaram-se e houve o aparecimento de operárias que se comportaram como rainha.

Foram observados machos na colônia, filhos das operárias, que executavam trabalhos com cerume e desidratavam nectar.

São descritas outras observações referentes a reutilização de células vazias, oofagia, forma e tamanho de favos.

\section{I - INTRODUCTION}

Several studies on the oviposition process of Meliponine bees were made by Sakagami and co-workers. However, few were dedicated to 
oviposition in an orphan colony. Bassindale (1955), was one of the first to observe this behaviour in a queenless colony of Trigona gribodoi. Sakagami et al. (1964), working with Cephalotrigona femorata, also described the behaviour of stingless bees under orphan conditions. Nevertheless, it was in colonies of Partomona testacea that Sakagami and coworkers (1964) studied speciafically the behaviour of a queenless colony in relation to oviposition.

The colony of Plebeia saiqui that we studied in an experimental hive was received from Rio d'Oeste, State of Santa Catarina, Brazil, in December 1970. The condition of the colony was very good during the summer, when it had a healthy laying queen. However, by the middle of June 1971, we saw that the colony was orphan and there was no virgin queen to substitute the dead one. As the species is not easy to obtain, we decided to study the behaviour of the workers during their orphanhood.

\section{II - OBSERVATIONS}

\section{1 - Brood cell construction}

In a queenright conditions, Plebeia saiqui builds brood cells in regular and horizontal combs. Generally, such cells are simultaneously built in one or more combs; the cell construction is semi-synchronous (Sakagami \& Zucchi, 1974). Their provisioning is simultaneosly and is followed by oviposition by the queen.

When we started to observe the orphan colony of $P$. saiqui, it was strong and had plenty of bees, as well as honey and pollen pots (these had about $2 \mathrm{~cm}$ in diameter). The involocrum was thick, with many layers of cerumen. The beggining of cell construction in this colony was not simultaneous but at the end the cells were in the "collar phase" (open cells with elevated rims) at the same time. The duration of such building activities was variable (generally 5 to 6 hours, but could reach 23 hours). The construction started a few minutes after sealing the previous cells (about 15 minutes). We do not know what kind of stimulus was necessary to begin that construction.

The number of workers on the brood combs seemed not to vary very much. The same could be said of the colony's general condition. In the moment that the cells were in the "collar phase", the bees were moving much, resembling a "Brownian moviment"; they ran at random and sometimes tried to work on a cell or to add cerumen to it. (Fig. 2). We marked some bees (about 150) and observed that there was no fixed kind of work on the region of comb for each of them.

The greatest concentration of bees on the comb was observed when the cells were in the "collar phase" It was difficult to distinguish the arousal phase because there is no queen in the colony. This phase was well described by Sakagami et al. (1974). However, we first observed that the bees grouped around different cells. These groupings could be 
considered as the end of the patrolling phase (Fig. 3). The excitation of the bees increased gradually. Each of them inserted the head inside the cell when inspecting it. The agitation went on until the moment when the bees "fought" each other to work on a cell (Fig. 4).

The excitation phase in the orphan colony of $P$. saiqui lasted a few seconds, in opposition to what was observed by Sakagami et al. (1964b) in Partamona testacea, when it lasted up to one hour, before the first discharge of larval food.

\section{2 - The provisioning of cells}

In $P$. saiqui the "releaser" to put the larval food inside the cell seems to be the vibrations of the wings. In this phase the number of workers on the comb decreased very much (Fig. 5). However, they soon returned, vibrating their wings. The movement of the bees that were provisioning was at first chaotic, reaching afterwards an apex of excitation. The process propagated as a wave and the beginning of it was observed in a region of the comb which had a great number of cells and workers.

The provisioning process was not perfectly simultaneous. It was observed that, many times, while some workers were ovipositing in a group of cells, others began to supply other more isolated cells. There was not a dominant worker. The same worker could build, as well as place provisions and lay in a cell. She could afterwards operculate and smooth the cell and even vibrate her wings on the comb. The discharges were sucessives and the number varied from 3 to 5 times.

The number of bees, the quantity of larval food and the duration of provisioning were variable. Generally there were about 20 cells to stock with food, and the process of provisioning, oviposition and sealing lasted about two minutes in all of them.

\section{3 - The oviposition process}

Oviposition occurred soon after the provisioning of the cells. The laying worker had a very characteristic position. She inserted the abdomen on the tip of the cell and opened her wings a little, while she contracted the abdomen to deliver the egg. The process was very quick and normally the egg was put in the center of the cell. It had the same size and colour as an egg of the queen.

In relation to the oviposition process, it was observed:

a) one of the bees which put the larval food into the cell could be the ovipositer.

b) while some workers put the larval food, one of them stayed outside the cell as if it was "fixing" and in a certain moment it layed an egg.

c) many times, during provisioning, some workers pushed each other, trying to lay an egg, without looking inside the cell.

d) the number of ovipasitions in a cell could vary (Table I).

Several cases were observed:

d1 - only one oviposition followed by operculation of the cell. 
TABLE 1 - Frequency of the contents of the cells, in one comb of the orphan colony of $P$. saiqui.

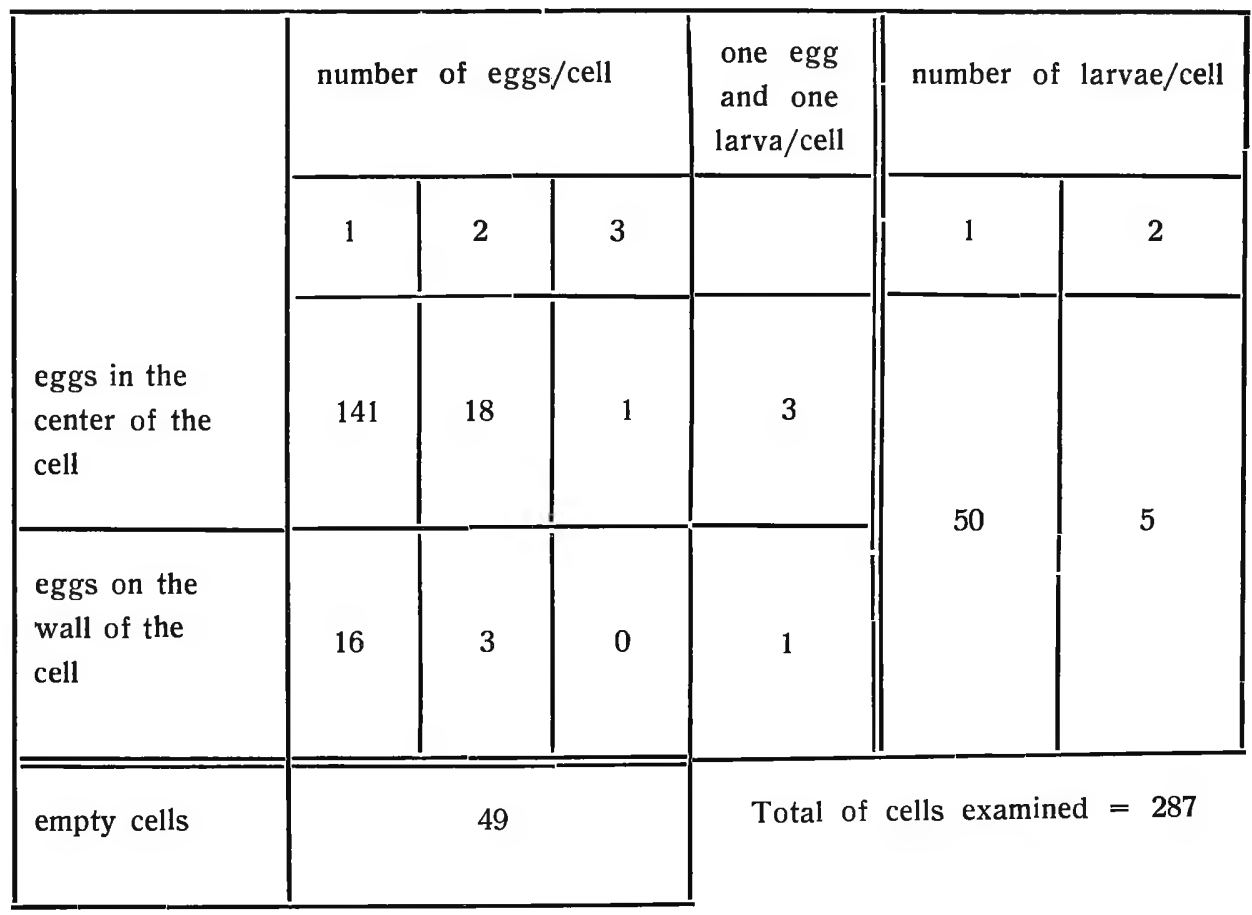

d2 - two or three ovipositions, one after the other, and the cell was closed with two or three eggs inside.

d3 - two to four ovipositions followed by oophagy. The cell could be closed empty or with one, two, three, or seldom, four eggs.

In relation to oophagy, the following behaviour normally occurred:

a) the worker which layed the first egg didn't start the cell operculation.

b) the worker left the cell withouth having closed it and another worker layed the egg and operculated it.

Generally when the worker layed an egg in the wall of the cell (not in contact with the larval food), the cell was not closed immediately, so it was common to occur a new oviposition without oophagy.

Many times oviposition didn't occur in all cells at the same time, although apparently these cells were in the same condition. Provisioning was possible to occur or not, but without oviposition.

After finishing oviposition, only a few workers smoothed the cells which had been just operculated. This phase showed a smaller number 
of workers on the comb. Occasionaly some workers could vibrate their wings, as it was also observed by one of us (VLIF) in queenright colonies of Paratrigona subnuda.

We didn't observe difference between the oviposition in common and queen cells.

\section{4 - The operculation of the cells}

After oviposition the operculation of the cells was started Generally this operculation was similar to that made by other Meliponinae, showing two phases: abdominal and mandibular (for operculation phases see Sakagami and Zucchi, 1963). The abdominal sealing could be done or not by the same worker that had oviposited. When this happened, we observed competition among the workers in relation to the cell. The workers tried to remove the bee which had put the egg. As they didn't succeed, they tried to help the operculation outside the cell. At the end, when the ovipositer left the cell, we observed a chink.

The mandibular closing of the cell was done by the ovipositer or by the bees which were in the comb region. The number of workers which closed the cell could differ and also the time duration of the closing (Fig. 6).

\section{5 - Miscellaneous observations}

A - To observe the oviposition, many times we had to remove the involucrum. It was then that one of us (MACO) noted an advancement of the "arousal" phase when the window of the hive was opened and the cells were in the "collar phase" The vibration of the wings started with a disorganized movement of the workers and also with provisioning and oviposition in the cells. Other stimuli, such as little beatings on the window in the combs region, determined alarm followed by provisioning and oviposition in the cells that were ready. However, this behaviour was modified in the final phase of the construction period. To obtain the response we had to intensify the stimulus, reaching a point when the bees didn't answer any more (habituation).

B - During the opening of the involucrum, the cell walls were spoiled many times. Normally, in queenright colonies of other Meliponinae, when a cell is damage there is oophagy and the larval food taken out, without reutilization of the cell. However, we observed a different behaviour, which determined other tests. Cells were opened between two following ovipositions:

a) immediately after finishing an oviposition.

b) twenty-four hours after an oviposition.

In both cases we had:

1 - oophagy followed by oviposition and operculation. 
2 - lack of oophagy, and another oviposition or ovipositons and operculation.

3 - oophagy and removal of the larval food. Many times after an excitation phase, the bees put the larval food in the cell and a worker layed an egg. By this time, even the cells that were built in the collar phase, didn't receive the larval food.

4 - oophagy followed by the closing of a cell, without oviposition or removal of the larval food.

During our observations, we thought that the larval food could be the "releaser" to the oviposition. This fact would explain the lack of this process in cells that were ready and had not received larval food yet. In order to observe the behaviour of the bees, we put in the cells some liquid substances such as water and honey (obtained from the pots). In both cases an alarm moviment was observed, then the workers ran in direction of the cells and removed the liquids.

C - We took out one comb to count the number of eggs in the cells. The comb which was just bellow the uppermost one had the central cells demaged and the prepupae which were in them died. They were taken out and the space was used again to build other cells. In this comb there were some cells which had grew addle before and the bees didn't use them.

$\mathrm{D}$ - When the building of cells in queenless condition began, there were no combs in the colony; generally in this genus there is not cell construction in the winter. Ten combs were built in the hive in queenless condition. During the building of the second one, we observed a tendency for the helicoidal type of construction. Later the horizontal disc shape was restored. Each comb had about three hundred cells, except the first and the last comb, which presented a smaller number (Fig. 1).

Only on the seventh comb there was a royal cell in the rim. This cell was built after the males' eclosion (Fig. 7).

We observed in the combs some spaces (discontinuities) united or not by pillars of cerumen. The explanations for this type of architecture is not known yet.

\section{$\mathrm{E}$ - The behaviour of males}

The first male was born on August 26th. By this time, the general condition of the colony was not very good, but brood cells were built.

On August 30th we observed that the construction of cells was slower. The collars of the open cells were ready and had been worked for a long time. It is possible that the appearance of males could influence the hive condition. The bees put small pellets of cerumen on the pots and the colony acquired a typically "orphan aspect" The small of the hive didn't change vary much.

Males of different sizes were observed. Some of them were very small and others very big. This fact could be explained because of the different quantities of larval food placed in the brood cells besides the 
number of eggs from each cell. The males which were recently born stayed over the combs. Trophallaxis was frequent among them and the workers. Many males remained close together over the involucrum or in other part of the hive. Others ran over the pots and many stayed at the entrance. Some males had cerumen between their jaws, a fact which suggests that they worked with this material. A drop in the tongue of some males was observed many times; we don't know whether the nectar dehydrated is for their own alimentation.

\section{6 - Change of behaviour}

In the beggining of September, when observing ovipositions, we verified that this process occurred in a different way:

a) Many workers stayed around a cell forming a court, and then they began the provisioning of it. We observed this behaviour in two cells at the same time.

b) Sucessive workers fixed the same cell. They stayed around the collar, moving the head and antenae and sometimes looking into the cell.

c) Oviposition was performed by the worker which touched with her antenae the head and the thorax of the worker which was already fixing the cell, as the queen does in the queenright colony. About five workers presented this behaviour. These workers didn't differ from other workers of the colony, they didn't have normally a court around them.

By this time, the construction of the cells was proceeding slowly (about 2 or 3 days for one cell). Many times there were destroyed. The involucrum had a rugose aspect. Deposition of cerumen pellets, which are very typic in orphan colonies of Paratrigona subnuda (I-Fonseca) was not observed. The number of workers which layed eggs into the cells decreased very much. For a few days the laying behaviour first described in this paper was restored. In the beginning of October the males were attacked and killed by the workers.

\section{DISCUSSION AND CONCLUSION}

The absence of a typically looking orphan colony, observed in $P$. saiqui is very uncommon. Nogueira-Neto (1970) writing about some Trigonini such as a Plebeia sp., stated that when queenless, these bees build apparently normal combs. This author observed that orphan colonies of meliponines generally can be recognized by the presence of small and irregular combs.

As the $P$ saiqui combs showed an irregular aspect only at the end of our observations, we can suggest an hypothesis to explain this fact. Strong colonies of Plebeia normally have many bees (about 4000). The queen and the males are the hardiest members of the colony. It is rare to observe orphan colonies of Plebeia with such a great number of workers without a virgin queen to substitute the dead one. In our case the mated 
queen must have died by accident, leaving in the colony a number of workers large enough to keep the colony with its normal aspect. This maybe is due to a group effect of a large number of bees. The facts which give support to our hypothesis are the regularity and homogeneity of the oviposition process, the great diameter of the combs $(8 \mathrm{~cm}$-about 300 cells) and the general conditions of the constructions and also of the gathering.

The cases of orphan Meliponinae colonies described by Sakagami et al. (1964a and b) were based on observations made on weak colonies, with small number of individuals, which had lost their laying queen.

In relation to the reutilization of the empty space in the combs, this was already observed in other Meliponinae such as Melipona rufiventris flavelineata and Paratrigona subnuda (Imperatriz and Ceccatto, 1970). In orphan colonies of Melipona marginata the reutilization of the brood cells was observed by A. R. de Carvalho (personal information). When the colony became weaker, an irregular process of oviposition appeared.

About the oviposition of workers we observed the same behaviour seen in other orphan colonies mentioned above, that is to say, one or more ovipositions in the same cell. The egg position in the cell is important in the operculation of it. When the cell is near the wall it is not operculated as it was observed in $P$. subnuda by Imperatriz-Fonseca (n-p.)

Histological sections were not made of the workers' ovaries. However we could observe their development indirectly. On the day in which we started the observations (May 17th, 1973) no new workers were born in the hive. Therefore when the oviposition period started, the workers were about 40 days old. Such period of ovary development is not common among the Meliponinae, even in orphan colony As an explanation it may be said that such workers were born in winter. It was observed by Murizio (1967), in Apis mellifera, that there is a difference between the longevity and the physiological state of the bees of two generations, in colonies of temperate regions. That author notes also that longevity is greater in orphan colonies. This longevity, according to Maurizio, could be related with the bees' alimentation and with their way of life.

Generally, on the winter there are diapauses in the colonies of Plebeia (emerina, droryana, remota, saiqui) in São Paulo. In July 1971 there were about 20 colonies of Plebeia sp. in the laboratory and only the orphan colony was building cells. A year before Imperatriz-Fonseca had seen cell construction in Plebeia remota in winter time. The colony was not strong and had a recently mated queen. This period of construction was very short. Those observations made us think that the maybe the queen has some influence on the diapause in Plebeia and this being associated, as well, with sudden variation in external temperature.

Furthermore, as regards the kind of work executed by the males on Meliponinae colonies, it was verified (Imperatriz-Fonseca 1973) that males of Schwarziana quadripunctata dehydrated nectar, worked as nectar receivers in the hive entrance and worked with cerumen in the involucrum. 
Silva (1973) observed that males of Melipona quadrifasciata anthidioides produce wax, like workers. These males don't put their wax in the same place as the workers, but they put it over the pots, involucrum or combs in the hive.

\section{ACKNOWLEDGEMENTS}

We wish to express our thanks to Fundação de Amparo à Pesquisa do Estado de São Paulo, for the support to the present work; to Dr. Paulo Nogueira-Neto for the reading and helpful suggestions.

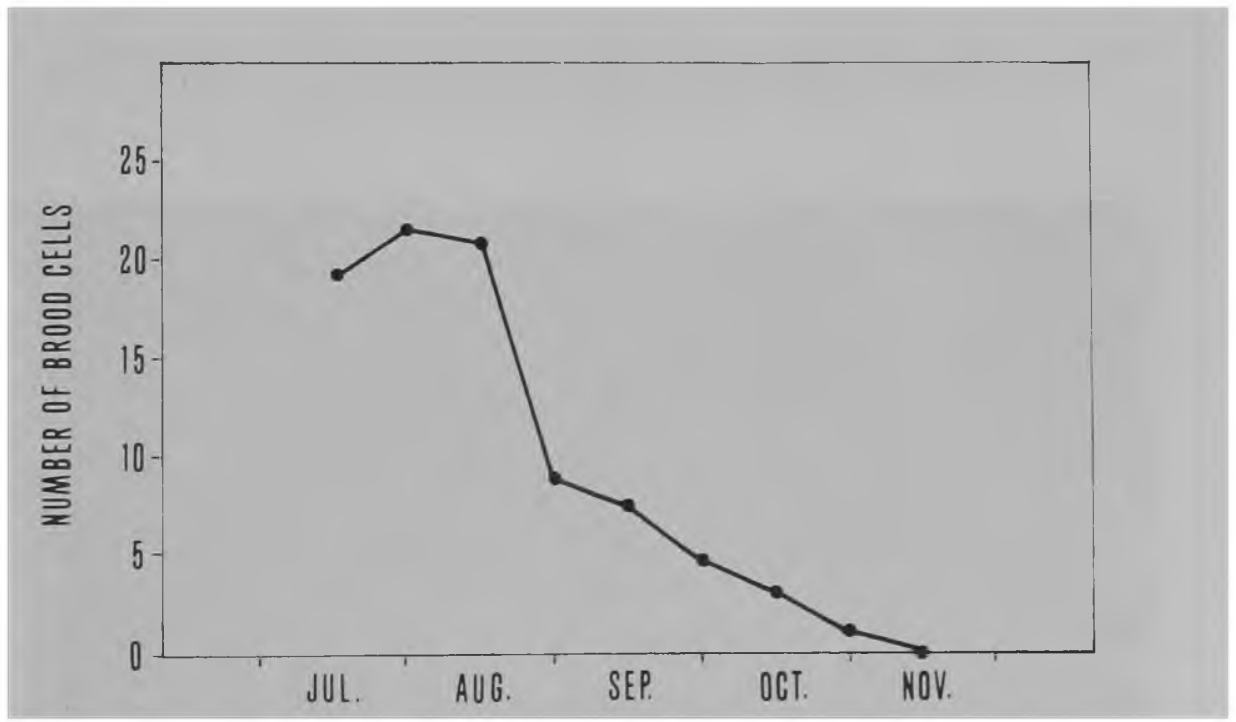

Fig. $1-P$ saiqui - Number of brood cells of oviposition process from July to November (daily means). 


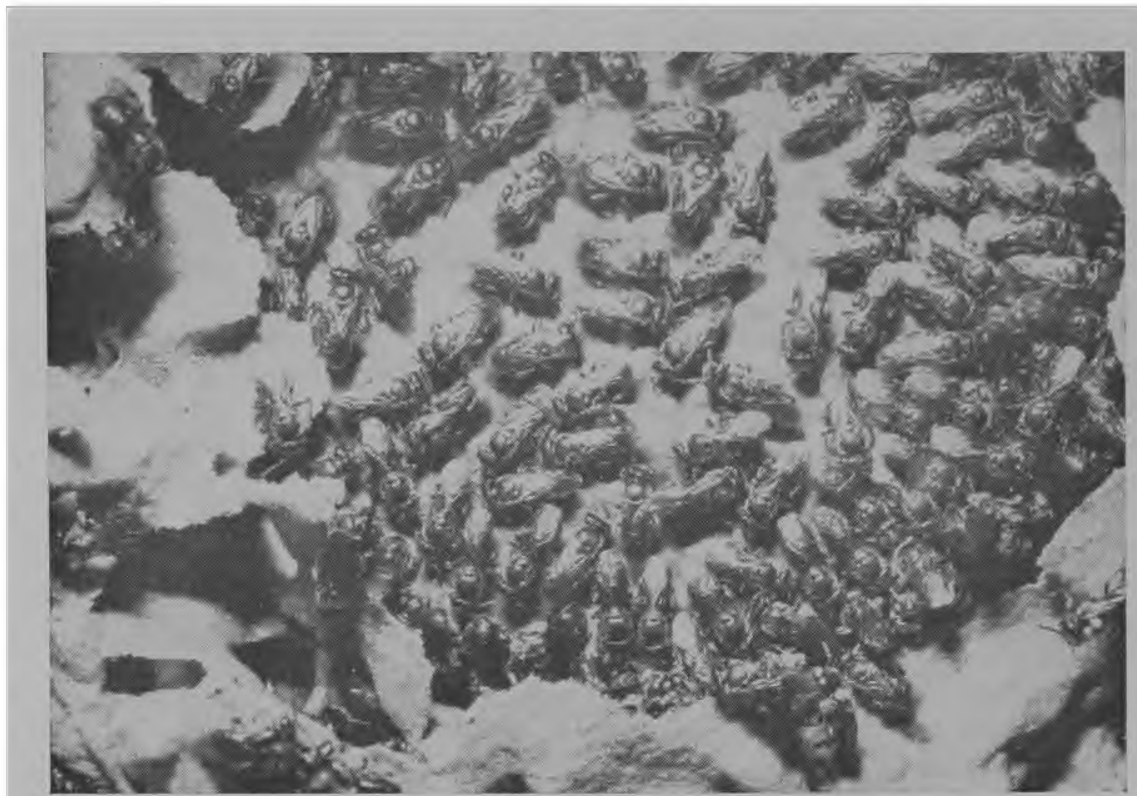

Fig. 2 - Bees working in cells during the "collar phase" There bees move at random, without any fixed kind of work for each of them.

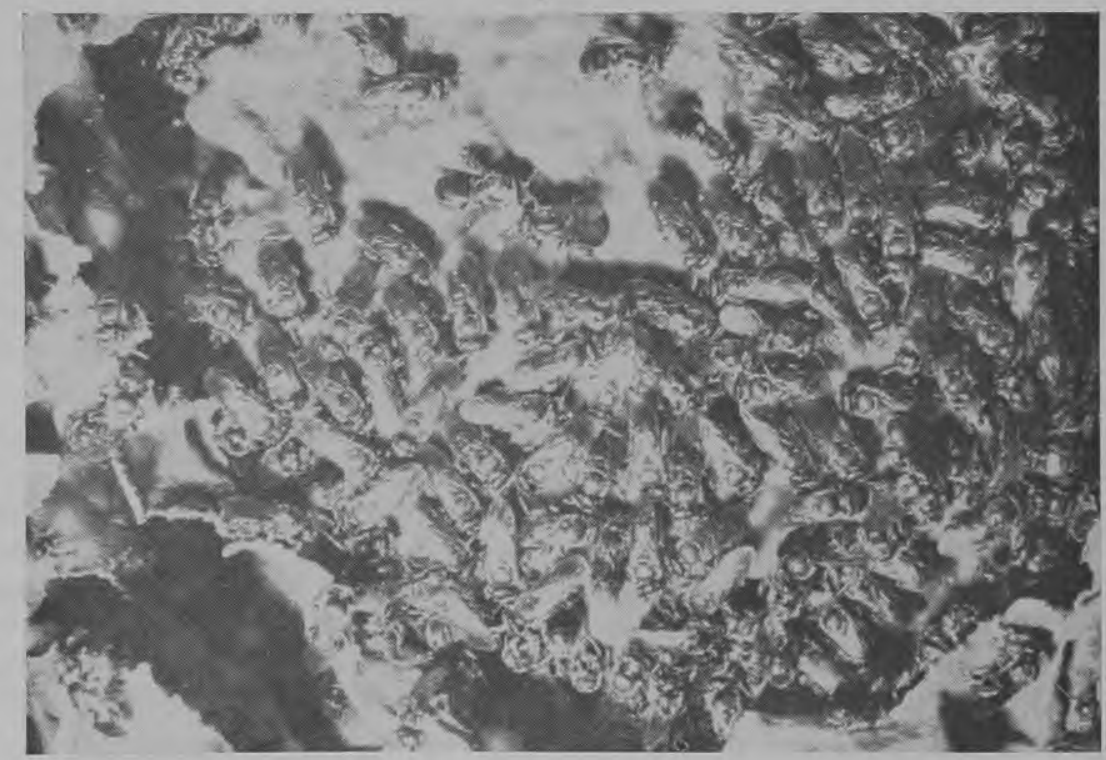

Fig. 3 - Groups of bees in a pre-fixation phase. The bees group around different ready cells, trying to reach them very rapidly. 


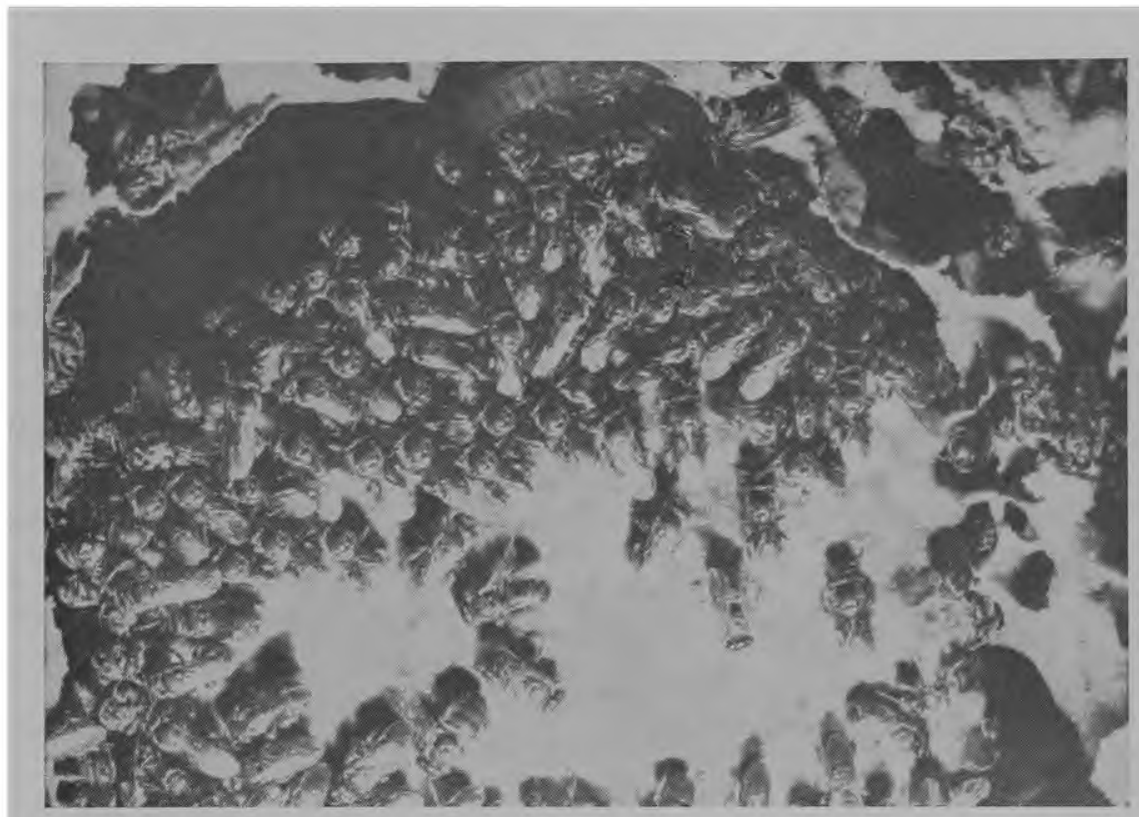

Fig. 4 - Bees trying to work on a cell. There are some workers, in the center of the comb, vibrating their wings.

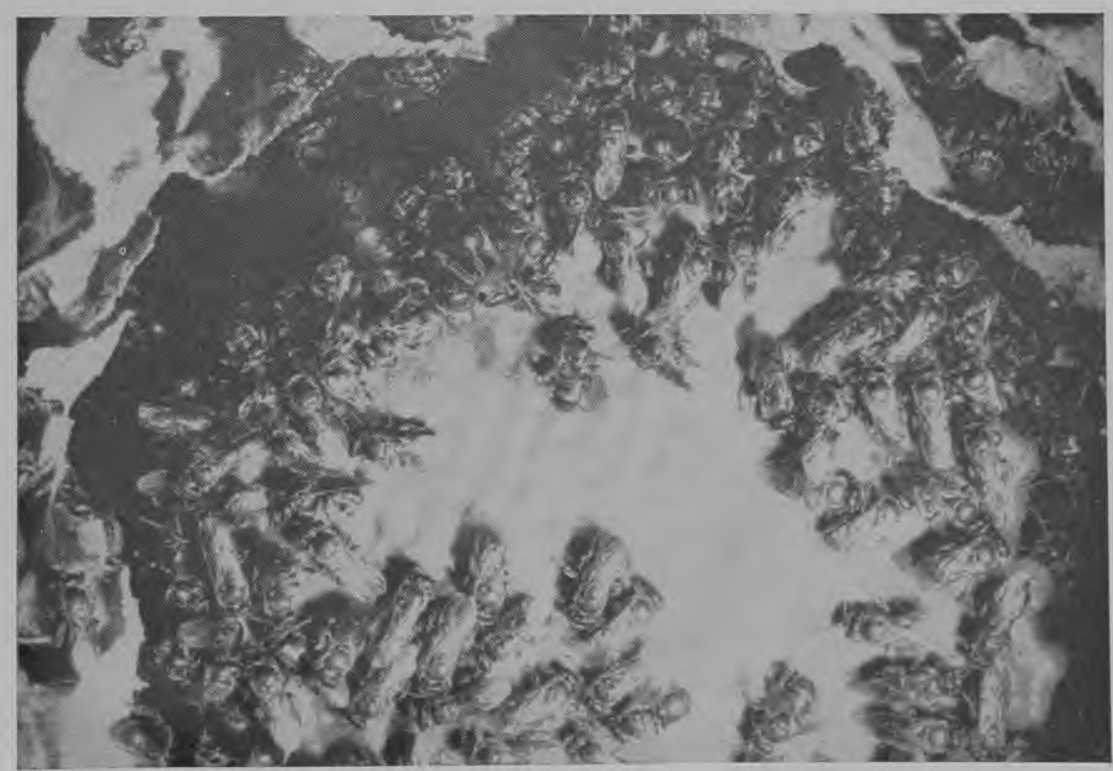

Fig. 5 - The provisioning process. The workers going out of the hive, in order to bring some food to put in the cells. 


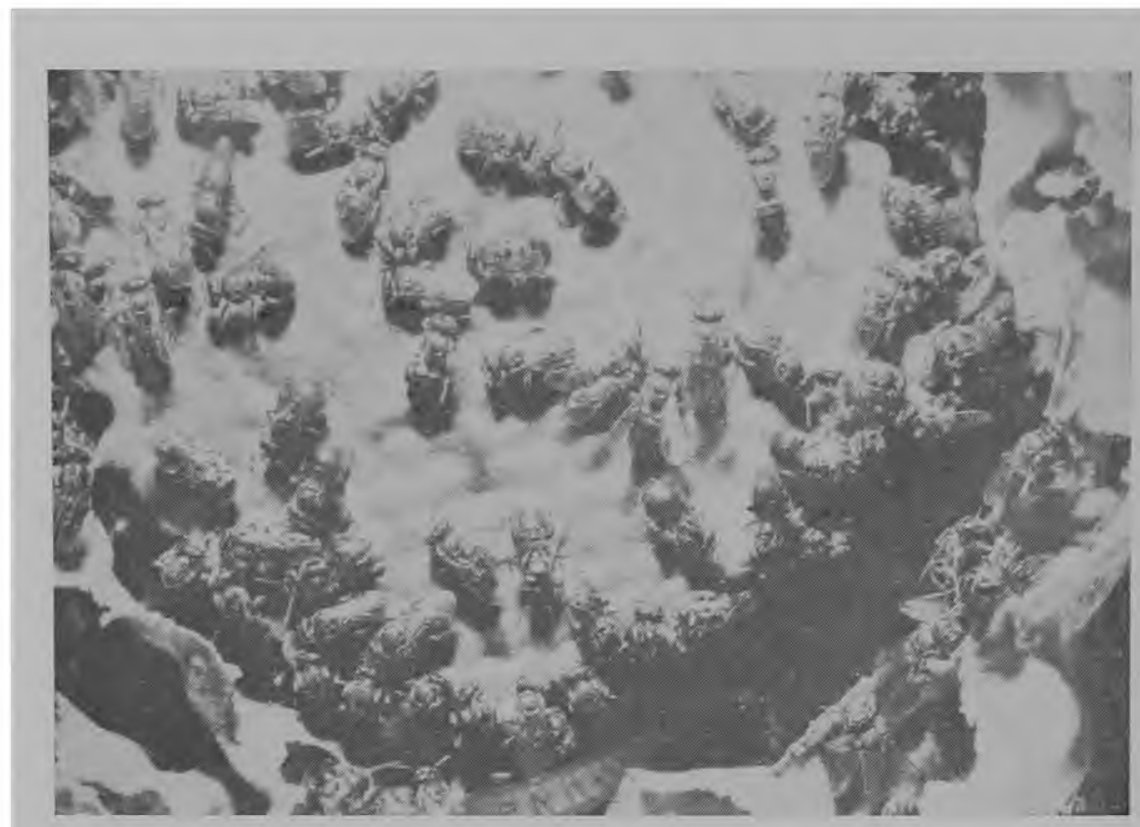

Fig. 6 - The operculation of the cells.

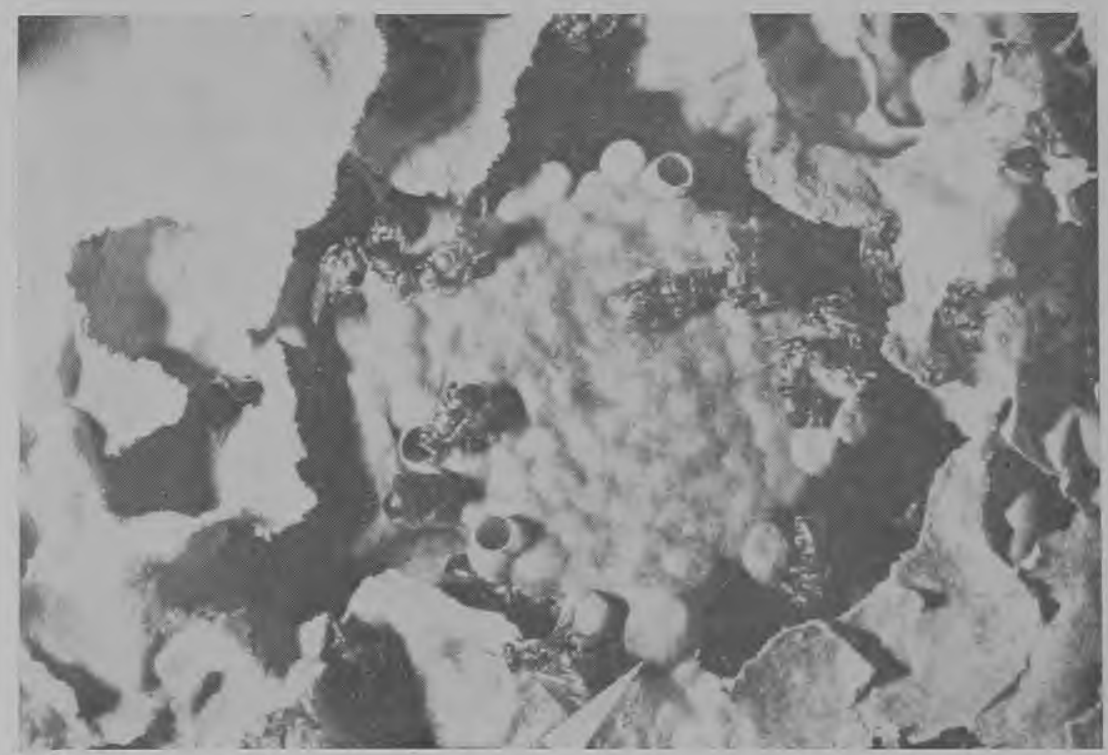

Fig. 7 - Royal cell (arrow). 


\section{REFERENCES}

BASSINDALE, R. - 1955 - The biology of the stingless bee Trigona (Hypotrigona) gribodoi Magr. Proc. Zool. Soc. Lond. 125:49-62.

IMPERATRIZ-FONSECA, V.L. and CECCATO, S. - 1970 - Reaproveitamento de espaços do favo em Melipona rufiventris flavolineata e Paratrigona subnuda (Moure). Ciência e Cultura, suplemento 22: 292.

IMPERATRIZ-FONSECA, V.L. - 1973 - Miscellaneous observations on the behaviour of Schwarziana quadripunctata (Hym. Apidae Meliponinae). Bol. Zool. e Biol. Mar., N.S., 30: 633-640.

MAURIZIO, A. - 1968 - Evolution et longévité des adultes. In "Traité de Biologie de l'Abeille", 1: 129-140.

NOGUEIRA-NETO, P. - 1970 - A criação de abelhas indigenas sem ferrão. São Paulo, Ed. Chacaras e Quintais. $365 \mathrm{pg}$.

SAKAGAMI, S.F.; D. BEIG \& C. KYAN - 1964a - Behaviour studies of the stingless bees, with special reference to the oviposition process. IV - Cephalotrigona femorata Smith. Kontyu, 32(4): 464-471.

SAKAGAMI, S.F.; D. BEIG \& Y. AKAKIRA - 1964b - Behaviour studies of the stingless bees with special reference to the oviposition process. III - Appearence of laying workers in a orphan colony of Partamona (Partamona) testacea testacea (Klug). Jap. J. Ecol. $14(2): 50-57$.

SAKAGAMI, S.F. and R. ZUCCHI - 1974 - Oviposition Behaviour of two dwarf stingless bees, Hypotrigona (Leurotrigona) muelleri and $H$. (Trigonisca) duckei, with notes on temporal articulation of oviposition process in stingless bees. $J$. Fac. Sci. Hokkaido Univ., Ser. VI, Zool., 19(2):361-421.

SILVA, D.L.N. - 1973 - Estudos bionômicos em colônias mistas de Meliponinae (Hymenoptera, Apoidea) — Thesis. Ribeirão Preto Fac. Fil. Univ. São Paulo. 144 pp. 
